\title{
BEHAVIORAL ALTERATIONS INDUCED BY ABSENCE OF CIRCADIAN LIGHT RHYTHM: EFFECTS OF CONSTANT LIGHT OR CONSTANT DARK ON DEPRESSION-LIKE BEHAVIORS AND LOCOMOTOR ACTIVITY IN RATS
}

\author{
ALTERAÇÕES COMPORTAMENTAIS INDUZIDAS PELA AUSÊNCIA DO RITMO \\ CIRCADIANO DE LUZ: EFEITOS DA LUZ CONSTANTE OU ESCURO CONSTANTE \\ EM COMPORTAMENTOS RELACIONADOS À DEPRESSÃO E NA ATIVIDADE \\ LOCOMOTORA EM RATOS
}

\author{
Marcelo Tadeu MARIN ${ }^{1,2}$; Túlio Teixeira ARAÚJO' ${ }^{1}$; \\ Marina Monteiro Figueiredo REZENDE ${ }^{\mathbf{1}}$; Érika Renata RIBEIRO-BARBOSA ${ }^{\mathbf{1}}$ \\ 1. Institute of Biomedical Sciences, Federal University of Uberlândia - UFU, Uberlândia, MG, Brazil. marcelo@ fcfar.unesp.br; 2. \\ Laboratory of Pharmacology, School of Pharmaceutical Sciences, Univ Estadual Paulista - UNESP, Araraquara, SP, Brazil.
}

\begin{abstract}
Affective disorders have been linked to abnormal biological rhythms. Depression- and anxietyrelated behaviors can be altered following changes of daily periods of environmental light. The aim of this study was to investigate the effect of daily light cycle on both anxiety- and depressive-like behaviors of rats. Wistar male rats were exposed to constant dark or constant light during one week and compared to control animals exposed to 12/12h light/dark cycle regarding to anxiety-like behaviors and general activity on open field test and depressive-like behaviors on the forced swimming test. Data showed that rats exposed to one week of constant light exhibited increased number of quadrants crossed in the open field. No change on anxiety-like behaviors (time and quadrants crossed in the center of apparatus) was observed in the open field test. One week of constant dark increased the time of immobility behavior in the forced swimming test relative to control 12/12h light/dark treatment. Therefore, one week of continuous light induced locomotor hyperactivity and one week of continuous dark induced depressive-like behaviors following reestablishment of normal 12/12h light/dark cycle. Such data demonstrate the importance of light/dark environmental rhythm on mood changes and the significance of light/dark cycle control on behavioral studies.
\end{abstract}

KEYWORDS: Anxiety. Depression. Locomotor activity. Circadian rhythm.

\section{INTRODUCTION}

The rotation of Earth around itself and around the Sun causes daily and seasonal rhythms in light intensity, temperature, humidity, and more. To optimally adapt to these rhythms, most organisms (including humans) developed rhythms in almost every aspect of their body, involving gene expression, physiology, cognitive functions and mood (KRONFELD-SCHOR, EINAT, 2012). Affective disorders had been linked to abnormal biological rhythms for many years and diurnal and seasonal variations of mood had been incorporated into the diagnostic system of affective disorders and many sleep and rhythm-related changes were identified in patients suffering from depression and anxiety disorders (WIRZ-JUSTICE, 2007). Unipolar depression is described by an unpleasant (dysphoric) mood that is present most of the day as well as intense mental anguish, the inability to experience pleasure (anhedonia), and a generalized loss of interest in the world. The key feature of generalized anxiety disorder is unrealistic or excessive worry, lasting not minutes but continuously for six months or longer. The symptoms are motor tension (trembling, twitching, muscle aches, restlessness), autonomic hyperactivity (palpitations, increased heart rate, sweating, cold hands), and vigilance and scanning (feeling on edge, exaggerated startle response, difficulty in concentrating). The disorder sometimes follows an episode of depression.

A classical mood effect of abnormal rhythm is Seasonal Affective Disorder, i.e. a subtype of chronic depression that involves an ordinary sequential pattern of major depressive illness onset in winter months with full remission in the spring (GUPTA et al. 2013). This Seasonal Affective Disorder seems related to decrease of daily light exposure.

Laboratory animals have been used to examine consequences of daily light disruptions. Rodents exposed to continuous dark exhibit depressive-like behaviors in the forced swimming test (GONZALEZ, ASTON-JONES, 2008; LAU et al., 2011). Also reduction of daily light period to 5 or 8 hours produced depressive-like effects 
(PRENDERGAST, NELSON, 2005; ASHKENAZY et al., 2009a). To support the idea of environmental light on depression induction, some studies showed that short periods of bright light treatment reversed depression-like behaviors in rats (ASHKENAZY et al., 2009b) and humans (MONTELEONE, MAJ, 2008). However, a treatment with no light deprivation but instead an aberrant light cycle (ultradian cycle consisting of 3.5-h light and 3.5-h dark) is also capable to induce depressive-like behaviors compared to 12-h light and 12-h dark treatment (LeGATES Et al., 2012). Then, not only light deprivation but also the rhythm of light exposure seems to depress mood.

Few studies report the effects of circadian light disruptions on anxiety. However, it seems that the result is similar to depression signs. Rats exposed to reduction of light period to 5 hours daily exhibited anxiety-like behaviors on the elevated plus maze (ASHKENAZY et al., 2009a). Hamsters exposed to short day light periods ( $8 \mathrm{~h}$ light/day) since weaning also showed increased anxiety-like signs (Prendergast, Nelson, 2005). Moreover, mice exposed to constant light displayed reduced anxietylike behaviors (FONKEN et al., 2009). Conversely, there are no data of constant dark exposure on anxiety in rodents.

To test the effect of daily light on both anxiety- and depressive-like behaviors rats were exposed to constant dark or constant light and compared to control 12/12h light/dark cycle regarding to anxiety-related behaviors and general activity on the open field test and depressive-related behaviors on the forced swimming test.

\section{MATERIAL AND METHODS}

\section{Subjects}

Male Wistar rats from CEBEA-UFU (Uberlândia - MG, Brazil) were transferred to its animal facility at least 7 days before the start of the experiments and were housed within groups of three to five per standard plastic cages [19 (width) X 30 (length) X 13 (height) $\mathrm{cm} \mathrm{].} \mathrm{The} \mathrm{room} \mathrm{was}$ maintained at a temperature of $23 \pm 2{ }^{\circ} \mathrm{C}$ and $12 \mathrm{~h} / 12 \mathrm{~h} \mathrm{light/dark} \mathrm{cycle} \mathrm{(light} \mathrm{on} \mathrm{at} 7 \mathrm{am}$ ) during this habituation period with ad libitum water and food access. The experimental protocol was approved by the Ethical Committee for the Animal Utilization of Federal University of Uberlândia (CEUA 086/12) and the experiments were conducted according to the principles of the Brazilian College of Animal Experimentation (COBEA).

\section{Light/Dark cycle alteration}

Animals were separated into three treatment groups: Light/dark 12h/12h (animals maintained in the regular circadian light cycle with light on at 7 am), Light $24 \mathrm{~h} /$ day (animals maintained in the environment with continuous light on) and Dark 24h/day (animals maintained in the environment with continuous dark). The treatment began right before light off at $7 \mathrm{pm}$ when all rats' home cages were introduced in light-tight cabinet with ventilation and programed light schedule (Insight Ltda, Ribeirão Preto-SP, Brazil). Rats were kept in this cabinet during 7 days after which light/dark cycle returned to 12/12h. All three treatment groups were exposed to light/dark cycle alteration on the same time, each one in a separated compartment of the cabinet with a independent programed light schedule. During this 7 day's period rats were not disturbed except for cleaning cages and water and chow replacement.

\section{Open field}

The open field apparatus is a circular arena of $90 \mathrm{~cm}$ in diameter surrounded by opaque walls 40 $\mathrm{cm}$ high made of wood painted with white waterproof paint. The opaque white floor was divided by lines into nine central and sixteen peripheral quadrants of equivalent area. The animals were placed in the center of the apparatus and the number of quadrants crossed (all four paws into an quadrant) was quantified during $5 \mathrm{~min}$ for assessment of peripheral, central and total locomotion using the software OpenFLD (developed by Stéfano P. Johann, http://blog.sbnec.org.br/2010/07/softwares) at the moment of test. Rearing frequency and number of fecal boli were also quantified. Locomotor activity was separately counted in the peripheral and central parts of the open field. Rodents spontaneously prefer the periphery of the apparatus to activity in the central parts of the open field since prey animals such as mice and rats avoid exposed areas (center of the open field). Increase of time spent in the central part as well as of the ratio central/total locomotion indicates anxiolysis and peripheral or total locomotion are indicatives of exploratory activity (see Prutt and Belzug, 2003 for review). Following each test rats returned to home cages and the apparatus was cleaned with $20 \%$ ethanol and dried.

\section{Forced swimming}

This procedure consisted in two phases: training and test. During training phase rats were individually introduced in cylindrical opaque plastic apparatuses $(25 \mathrm{~cm}$ diameter $\times 60 \mathrm{~cm}$ high) with a 
water column of $45 \mathrm{~cm}$ from which the animal was not able to escape. Rats remained in the water for 15 minutes. Forced swimming test was performed 24 hours after training and consisted of introductions of the rat in the water container for behavioral measures during $5 \mathrm{~min}$. During test phase the animal was recorded by a camera located above the apparatus for later behavioral quantification. In this paradigm immobility is interpreted as a passive stress-coping strategy or depression-like behavior (behavioral despair) (DEUSSING, 2006). Immobility behavior was quantified measuring the period of absence of vertical or horizontal animal movements, except limb movements to maintain nose and ears above water surface. After each swimming session, rats were towel-dried and put back in their home cages. The apparatuses were cleaned and temperature adjusted water $\left(25 \pm 1{ }^{\circ} \mathrm{C}\right)$ was replaced after each swimming session.

\section{Experimental procedure}

Rats ( $N=8-9$ per group) were first submitted to light/dark cycle alteration during 7 days. On day 8 (15 hours after the end of light/dark cycle alteration, 3 hours after the beginning of light phase for all groups) animals were tested in the open field. On the same day (3 hours following open field test) animals were exposed to forced swimming training. On day 9 animals were tested on the forced swimming. All procedures were performed during the light phase of light/dark cycle.

\section{Statistics}

Statistical analysis was performed using Statistica software. All values were expressed as mean + SE. The results were analyzed by one-way analysis of variance (ANOVA) considering the factor treatment (Light/dark 12h/12h vs Light 24h/day vs Dark 24h/day). In cases where ANOVA showed significant differences $(\mathrm{p}<0.05)$ the Newman-Keuls post hoc test was performed.

\section{RESULTS}

Figure 1 shows behavioral results in the open field apparatus. First, ANOVA revealed a significant difference for peripheral locomotion in open field $\left(\mathrm{F}_{2,22}=4.62, \mathrm{p}<0.05\right)$. Newman-Keuls post hoc test showed increased peripheral locomotion in the Light $24 \mathrm{~h} /$ day group compared to Light/dark 12h/12h and Dark 24h/day groups ( $\mathrm{p}<$ $0.05)$. Central locomotion was not altered by light/dark cycle alteration $\left(\mathrm{F}_{2,22}=0.94, \mathrm{p}=0.41\right)$ but total locomotion (quadrants crossed in the central plus peripheral parts of open field) was significantly altered $\left(\mathrm{F}_{2,22}=4.69, \mathrm{p}<0.05\right)$. Newman-Keuls post hoc test revealed increased total locomotion in the Light 24h/day group compared to Light/dark $12 \mathrm{~h} / 12 \mathrm{~h}$ and Dark 24h/day groups $(\mathrm{p}<0.05)$. ANOVA showed no significant effect of treatment for the other measures such as time in the central part of open field $\left(\mathrm{F}_{2,22}=2.58, \mathrm{p}=0.10\right)$, rearing behavior $\left(\mathrm{F}_{2,22}=2.71, \mathrm{p}=0.09\right)$ and defecations $\left(\mathrm{F}_{2,22}=0.54, \mathrm{p}=0.59\right)$.
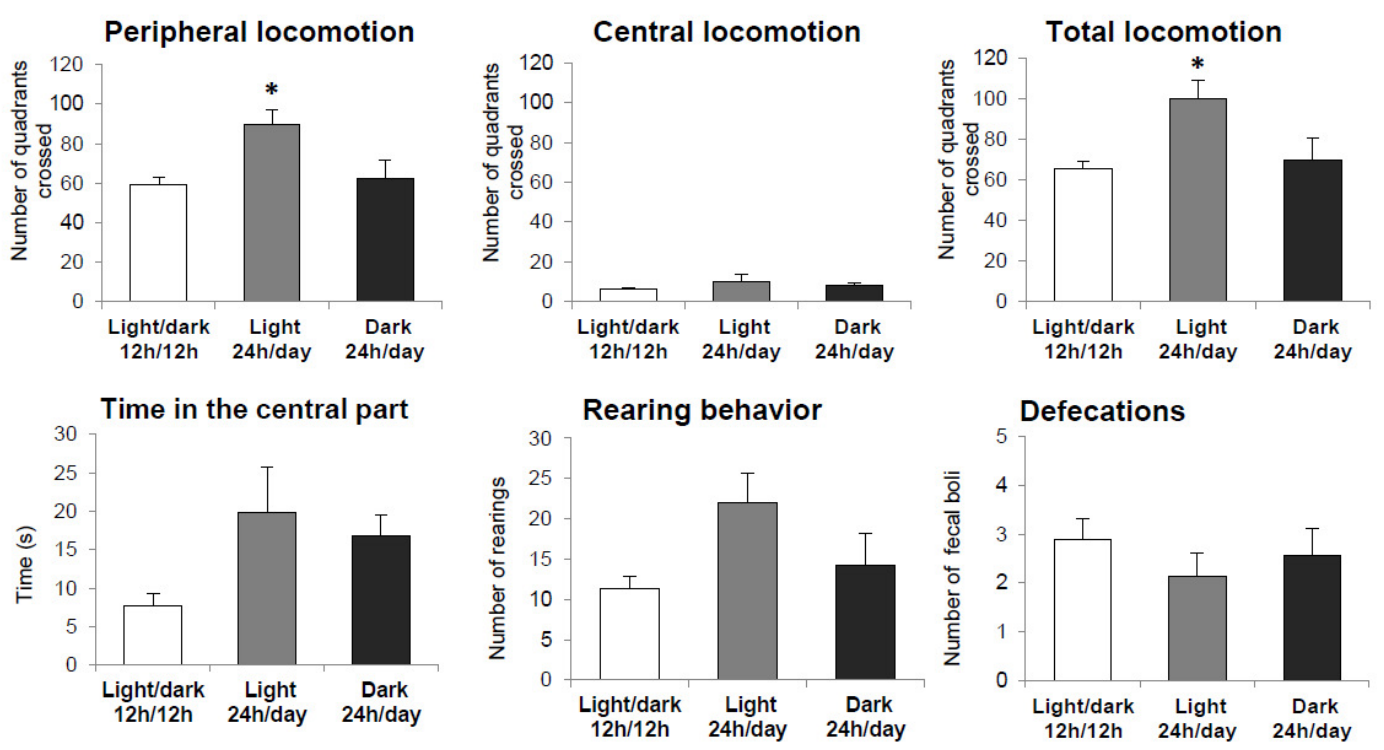

Figure 1. Behaviors in the open field of rats exposed during one week to control $12 \mathrm{~h} / 12 \mathrm{~h} \mathrm{Light/dark}$ cycle, continuous light (Light 24h/day) or continuous dark (Dark 24h/day). Bars represent means \pm S.E.M. ( $\mathrm{N}=8-9$ animals per group). $* \mathrm{p}<0.05$ compared to all other groups (Newman-Keuls post hoc test). 
Figure 2 contains data obtained from forced swimming test. The immobility, a depressionrelated behavior, was significantly altered by treatment as shown by ANOVA $\left(\mathrm{F}_{2,22}=3.75, \mathrm{p}<\right.$
0.05). Newman-Keuls post hoc test showed increased immobility behavior in the Dark 24h/day group compared to Light/dark $12 \mathrm{~h} / 12 \mathrm{~h}$ group $(\mathrm{p}<$ $0.05)$.

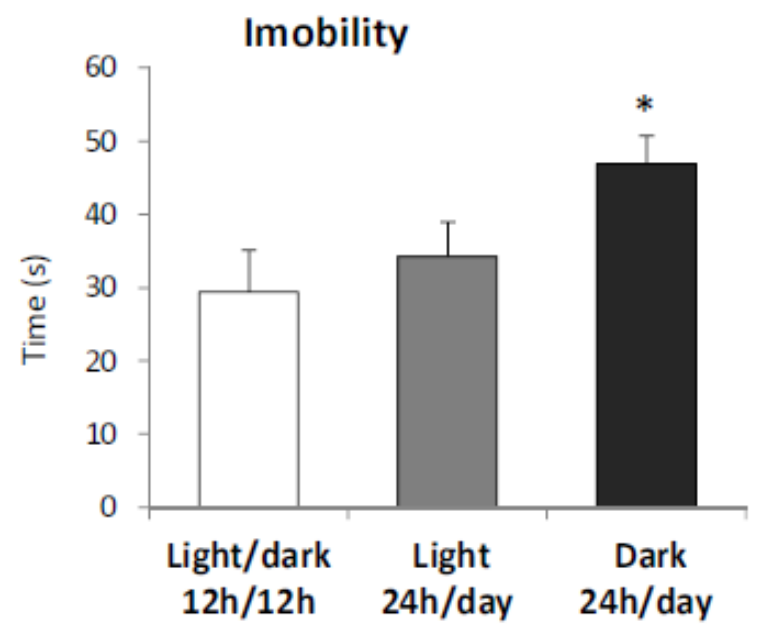

Figure 2. Immobility behavior in the forced swimming test of rats exposed during one week to control $12 \mathrm{~h} / 12 \mathrm{~h}$ Light/dark cycle, continuous light (Light 24h/day) or continuous dark (Dark 24h/day). Bars represent means \pm S.E.M. $(\mathrm{N}=8-9$ animals per group). $* \mathrm{p}<0.05$ compared to $12 \mathrm{~h} / 12 \mathrm{~h}$ Light/dark cycle group (Newman-Keuls post hoc test).

\section{DISCUSSION}

In addition to being necessary for vision, light also plays a primary role in circadian physiology. Light is the main environmental cue used by the circadian clock to achieve this synchronization with the day-night cycle. The primary pacemaker of the mammalian circadian system is located in the suprachiasmatic nucleus of the hypothalamus. The light signal reaches the suprachiasmatic nuclei mainly through a dedicated pathway, the retinohypothalamic tract, which contain cells that alter their level of activity according to light intensity in the environment (DUMONT; BEAULIEU, 2007). The endogenous biological clock allows the organism to anticipate the changes in the environment that are associated with day and night in order to function optimally. Since most human physical and mental functions exhibit circadian rhythmicity, alterations in the endogenous mechanisms regulating circadian oscillations may lead to physiological and emotional pathologies (MONTELEONE; MAJ, 2008).

In this study animals exposed to one week of constant light exhibited locomotor hyperactivity and one week of constant dark exhibited depressivelike behavior relative to control 12/12h light/dark treatment. Both constant light and constant dark treatments had absence of light as a circadian cue for biological clock synchronization. However, only the no light treatment caused depressive-like signs. This effect is corroborated by investigations showing that constant dark (GONZALEZ, ASTONJONES, 2008; LAU et al., 2011) or daily light period reduction (PRENDERGAST, NELSON, 2005) increased immobility in the forced swimming test. This phenomenon of depression induction by light absence seems to be mediated by the melatonin hormone. Melatonin is secreted by the pineal gland and is elevated during periods of light absence. Its release is controlled by the suprachiasmatic nuclei, which stimulates melatonin secretion at night (KLEIN et al., 1991; KRONFELD-SCHOR; EINAT, 2012). Melatonin administration to rats during the light hours showed to induce similar effect on behaviors related to depression to those of exposure to daily light period reduction (ASHKENAZY et al., 2009a). There are also evidences of melatonin secretion alteration in depressed humans; however other hormones, such as cortisol, and other physiological variables are likewise altered (LANFUMEY, 2013).

The constant light treatment in our study did not alter depressive-like behavior in the forced swimming test. Despite results showing that 1h/daily treatments with bright light decrease depressive-like behaviors (ASHKENAZY et al., $2009 \mathrm{~b}$ ), our study showed that constant environmental light could not ameliorate depression-like signs. Nevertheless, Fonken et al. 
(2009) showed that mice exposed to three weeks of constant light increased the depressive-related behaviors in the forced swimming test and sucrose consumption test of anhedonia. Though, the different results between our study and that from Fonken et al. may be due to different employed species (mice vs. rats), treatment duration (3 weeks vs. 1 week) and the control group. They compared the constant light treatment with a $16 / 8 \mathrm{~h}$ light/dark control treatment while we used a 12/12h light/dark control group. Small circadian light changes such as $14 / 10 \mathrm{~h}$ light/dark already induces alterations of depressive-like behaviors compared to $12 / 12 \mathrm{~h}$ light/dark cycle (PRENDERGAST; KAY, 2008).

Anxiety-related behaviors following one week of constant light or constant dark were not altered in our experiment since the locomotion or time spent in the central part (more exposed part) of open field arena were not altered. Rearing frequency and defecations, measures also related to anxiety in some studies (PRUTT; BELZUG, 2003), were neither altered. Other study has found that mice exposed to constant light during three weeks exhibited reduce anxiety-related behavior in the elevated plus maze (FONKEN et al., 2009). Moreover, rats exposed to eight weeks of increased daylight period (14h light:10h dark) exhibited anxiolytic effect on open field compared to $10 \mathrm{~h}$ light:14h dark treatment (PRENDERGAST; KAY, 2008). Then, a longer period than one week of constant light or dark should be necessary for modifications of anxiety-related behaviors. Other apparatuses such as Elevated Plus Maze or LightDark Box could also be employed to quantify anxiety related behaviors. They are more specific to anxiety assessment than open field and results possibly different.
Our study showed that rats exposed to one week of constant light displayed increased exploratory activity measured by quadrants crossed in the periphery of open field. Constant dark exposure did not alter this variable. This locomotor hyperactivity may be due to a circadian locomotor arrhythmicity produced by continuous light. Similarly, Depres-Brummer et al. (1995) have shown that continuous light, but not continuous dark, exposure suppressed the circadian rhythm of locomotor activity and dampened melatonin circadian rhythm. Thus, considering that rats naturally have low locomotor activity during the light phase and the open field test of our study was performed during the light phase (15 hours following restoration of $12 / 12 \mathrm{~h}$ light dark cycle) continuous dark treated animals should be at the low activity phase of the day. Conversely, continuous light exposed animals should have a disruption of locomotor activity circadian rhythm and showed higher activity even during the light phase. This rhythm disruption might explain the locomotor hyperactivity in our animals exposed to continuous light treatment. In face of the data, we suggest that continuous light is more deleterious to circadian rhythms such as locomotor activity. Light inhibition of melatonin secretion may be related to this effect.

Therefore, rats exposed to environmental light alterations displayed behavioral disruptions. Continuous dark induced depressive-like behaviors and continuous light induced locomotor hyperactivity following return to an environment at normal 12/12h light/dark cycle. Such results demonstrate the importance of light/dark environmental rhythm on mood changes and the significance of light/dark cycle control on behavioral studies.

RESUMO: Os transtornos afetivos têm sido relacionados a anormalidades dos ritmos biológicos. Comportamentos relacionados à depressão e ansiedade podem ser alterados depois de mudanças dos períodos diários de luz ambiental. O objetivo desse estudo foi investigar o efeito de alterações no ritmo diário de luz em ambos os comportamentos relacionados à ansiedade e depressão em ratos. Ratos Wistar machos foram expostos a um ambiente com escuro constante ou claro constante durante uma semana e foram comparados aos animais controle (12h claro / 12h escuro) quanto aos comportamentos relacionados à ansiedade e atividade geral no teste de campo aberto e quanto aos comportamentos relacionados à depressão no teste de nado forçado após o restabelecimento do ritmo normal de claro/escuro. Os resultados mostraram que ratos expostos por uma semana no claro constante apresentaram aumento dos quadrantes percorridos no teste de campo aberto se comparados aos ratos controle. Nenhuma alteração dos comportamentos relacionados à ansiedade (tempo e locomoção no centro do aparato) foi observada no teste do campo aberto. Além disso, uma semana no escuro constante aumentou o tempo de imobilidade dos animais no teste de nado forçado quando comparados aos animais controle. Portanto, uma semana de claro constante induziu hiperatividade locomotora e uma semana de escuro constante induziu comportamentos relacionados à depressão depois do restabelecimento do ritmo normal $(12 / 12 \mathrm{~h})$ de claro e escuro. Tais resultados demonstram a importância do ritmo claro/escuro ambiental nas alterações de humor e a importância do controle do ciclo claro/escuro em estudos comportamentais. 
PALAVRAS-CHAVE: Ansiedade. Depressão. Atividade locomotora. Ritmo circadiano.

\section{REFERENCES}

ASHKENAZY, T.; EINAT, H.; KRONFELD-SCHOR, N. We are in the dark here: induction of depressionand anxiety-like behaviours in the diurnal fat sand rat, by short daylight or melatonin injections. Int $\mathbf{J}$ Neuropsychopharmacol., Cambridge, v. 12, n. 1, p. 83-93, feb. 2009a.

ASHKENAZY, T.; EINAT, H.; KRONFELD-SCHOR, N. Effects of bright light treatment on depression- and anxiety-like behaviors of diurnal rodents maintained on a short daylight schedule. Behav Brain Res., Amsterdam, v. 201, n. 2, 343-346, aug. 2009b.

DEPRÉS-BRUMMER, P.; LÉVI, F.; METZGER, G.; TOUITOU, Y. Light-induced suppression of the rat circadian system. Am J Physiol., v. 268, n. 5.2, p. R1111-1116, may 1995.

DEUSSING, J. M. Animal models of depression. Drug Discovery Today: Disease Models, v. 3, n. 4, p. 375383, 2006. http://dx.doi.org/10.1016/j.ddmod.2006.11.003

DUMONT, M.; BEAULIEU, C. Light exposure in the natural environment: relevance to mood and sleep disorders. Sleep Med., Amsterdam, v. 8, n. 6, 557-565, sep. 2007.

FONKEN, L. K.; FINY, M. S.; WALTON, J. C.; WEIL, Z. M.; WORKMAN, J. L.; ROSS, J.; NELSON, R. J. Influence of light at night on murine anxiety- and depressive-like responses. Behav Brain Res., Amsterdam, v. 205, n. 2, p. 349-354, dec. 2009.

GONZALEZ, M. M.; ASTON-JONES, G. Light deprivation damages monoamine neurons and produces a depressive behavioral phenotype in rats. Proc Natl Acad Sci USA., Washington, v. 105, n. 12, p. 4898-4903, mar. 2008.

GUPTA, A.; SHARMA, P. K.; GARG, V. K.; SINGH, A. K.; MONDAL, S. C. Role of serotonin in seasonal affective disorder. Eur Rev Med Pharmacol Sci., Rome, v. 17, n. 1, p. 49-55, jan. 2013.

KLEIN, D. C.; MOORE, R. Y.; REPPERT, S. M. Suprachiasmatic nucleus: the mind's clock. New York: Oxford University Press, 1991. 467p.

KRONFELD-SCHOR, N.; EINAT, H. Circadian rhythms and depression: human psychopathology and animal models. Neuropharmacology, London, v. 62, n. 1, p. 101-114, jan. 2012.

http://dx.doi.org/10.1016/j.neuropharm.2011.08.020

LANFUMEY, L.; MONGEAU, R.; HAMON, M. Biological rhythms and melatonin in mood disorders and their treatments. Pharmacol Ther., Oxford, v. 138, n. 2, p. 176-184, may. 2013.

LAU, B. W.; REN, C.; YANG, J.; YAN, S. W.; CHANG, R. C.; PU, M.; SO, K. F. Light deprivation induces depression-like behavior and suppresses neurogenesis in diurnal mongolian gerbil (Meriones unguiculatus). Cell Transplant., Elmsford, v. 20, n. 6, p. 871-881, 2011.

LEGATES, T. A.; ALTIMUS, C. M.; WANG, H.; LEE, H. K.; YANG, S.; ZHAO, H.; KIRKWOOD, A.; WEBER, E. T.; HATTAR, S. Aberrant light directly impairs mood and learning through melanopsinexpressing neurons. Nature, London, v. 491, n. 7425, p. 594-598, nov. 2012.

http://dx.doi.org/10.1038/nature11673

MONTELEONE, P.; MAJ, M. The circadian basis of mood disorders: recent developments and treatment implications. Eur Neuropsychopharmacol., Amsterdam, v. 18, n. 10, p. 701-711, oct. 2008. 
PRENDERGAST, B. J.; KAY, L. M. Affective and adrenocorticotrophic responses to photoperiod in Wistar rats. J Neuroendocrinol., v. 20, n. 2, p. 261-267, feb. 2008. http://dx.doi.org/10.1111/j.13652826.2007.01633.x

PRENDERGAST, B. J.; NELSON, R. J. Affective responses to changes in day length in Siberian hamsters (Phodopus sungorus). Psychoneuroendocrinology., Oxford, v. 30, n. 5, p. 438-452, jun. 2005.

PRUT, L.; BELZUNG, C. The open field as a paradigm to measure the effects of drugs on anxiety-like behaviors: a review. Eur J Pharmacol., Amsterdam, v. 463, p. 3-33, feb 2003.

WIRZ-JUSTICE, A. Chronobiology and psychiatry. Sleep Med Rev., Oxford, v. 11, n. 6, p. 423-427, dec. 2007. 